\title{
Dead birds found after aerial poisoning operations targeting small mammal pests in New Zealand 2003-14
}

\author{
Grant A. Morriss*, Graham Nugent and Jackie Whitford \\ Landcare Research, PO Box 69040, Lincoln 7640, New Zealand \\ *Author for correspondence (Email: morrissg@landcareresearch.co.nz)
}

Published online: 25 May 2016

\begin{abstract}
In New Zealand, aerial poisoning with 1080 (sodium fluoroacetate) bait is widely used for control of introduced small mammal pests in remote or forested areas. However this practice is controversial, partly because of perceived risks to native fauna, particularly birds. That perception originally derives from substantial mortality of some native bird species in pre- 1980 control operations, which prompted changes in baiting practice to mitigate most of the risk. However contemporary modifications to aerial baiting procedures - including sowing bait in strips or clusters, using prefeed, or adding deer repellent - may have renewed the risk to birds. Here we report observations on the number of dead birds found and on the relative abundance of certain bird species after 15 aerial baiting operations between 2003 and 2014. We found in total 81 bird carcasses, of which 84\% were introduced species (mostly blackbirds (Turdus merula)) and 16\% were native species (comprising eight kererū Hemiphaga novaeseelandiae, two tomtits Petroica macrocephala and one each of tūī Prosthemadera novaeseelandiae, fantail Rhipidura fuliginosa and silvereye Zosterops lateralis). Overall, significantly more bird carcasses were found per field day of searching effort after standard broadcast 1080 sowing than alternative bait distribution methods (strip- or cluster-sowing). Residues of 1080 were detected in $18 \%(2 / 11)$ of the native birds analysed (both tomtits), compared to $94 \%$ (33/35) of the introduced birds tested. Blackbirds comprised $80 \%$ of the introduced dead birds found, $96 \%$ of which $(25 / 26)$ contained 1080 residue. Furthermore, in two detailed studies conducted in the Hauhungaroa Ranges in 2011 and 2013, blackbirds represented 3.2\% and $1.9 \%$ of the overall live bird counts but $54 \%$ and $73 \%$ respectively of the dead birds found. Our results suggest that modern 1080 baiting operations pose only a negligible threat to native forest bird communities and a small threat to individuals, especially relative to the threats they face from the introduced mammals targeted in pest-control operations.
\end{abstract}

Key words: 1080; aerial poisoning; birds; by-kill; New Zealand; pest control; toxin residues

\section{Introduction}

For about 60 years, New Zealand has relied heavily on aerial poisoning of introduced small mammal pests to provide affordable landscape-scale protection of native plants and animals, reduced competition with livestock and control of wildlife-borne bovine tuberculosis (Wright 2011). The toxin used, sodium fluoroacetate (hereafter 1080), is not only lethal to the targeted pests (principally Australian brushtail possums (Trichosurus vulpecula) and ship rats (Rattus rattus)), but also to other introduced and native animals, including birds (Eason et al. 2011).

While the overall net benefits to conservation and disease management are considered by proponents to be strongly positive (Wright 2011), the non-target deaths ('by-kill'), particularly of native birds, has long been raised as a contentious issue by those opposed (for a variety of reasons) to aerial 1080 poisoning (Green \& Rohan 2012). This concern has its genesis in reports from the 1960 s and 1970 s of significant mortality of some native bird species after 1080 aerial poisoning operations (Spurr 1979, 2000). Since then, substantial changes in 1080 baiting practices (such as improvements in the consistency in bait size, the use of dye to make baits less attractive to birds and progressive reductions in 1080 sowing rates) have reduced the risk to many native bird species to low levels (Veltman \& Westbrooke 2011). Nevertheless, some non-target bird deaths still occur. Veltman and Westbrooke (2011) summarized the outcomes of 47 studies in which the mortality of radio-tagged native birds had been monitored during aerial 1080 operations: 48 of 748 birds $(6.5 \%)$ died or disappeared in 1080-treated areas, compared to only 4 of $193(2.1 \%)$ in areas not poisoned.

Importantly, the analyses reported by Veltman and Westbrooke (2011) noted that only nine of the 47 surveys they reviewed were based on operations employing contemporary best practices for mammalian aerial pest control (NPCA2010). Of particular relevance, best practice guidelines for aerial 1080 operations now stipulate prefeeding of a treatment area with non-toxic bait a few days before deployment of toxic bait in order to familiarize targeted pests with the bait; this increases subsequent pest consumption of toxic bait and consequent target species kill (Coleman et al. 2007; Nugent et al. 2011). However, prefeeding may also increase familiarization of native birds with the bait, thus potentially increasing by-kill (Veltman \& Westbrooke 2011). Furthermore, there is potential for increased or changed risk to native birds from new lowcost techniques for sowing 1080 bait, where bait is sown in clusters or strips (Nugent \& Morriss 2013). Although these new techniques use less toxic bait overall compared to the whole-area 'broadcast' sowing technique (typically 125-333 baits per ha for broadcast sowing versus $42-83$ baits per ha for strip/cluster sowing), they result in an increased localised density of bait in the baited parts of the operational area. Additionally, a deer-repellent compound surface coating is sometimes used on 1080 baits. This was developed to repel 
deer but not possums or rats during 1080 aerial operations (Speedy 2005; Morriss 2007), but its effects on the risk of by-kill of birds is unknown.

The efficacy of aerial 1080 operations in reducing numbers of target mammals is usually assessed by postpoison monitoring (such as trapping, ink-tracking or checking interference devices; Warburton \& Livingstone 2015). This requires the fieldworkers conducting such monitoring to traverse substantial amounts of the operational areas on foot, which thus provides an opportunity for them to collect other information related to the outcomes of control operations. The case in point for the present study is ground-scrutiny for the presence of by-kill, particularly for the enumeration, collection and examination of bird carcasses. In this paper we analyse data regarding dead birds recorded during the monitoring phases following 15 experimental aerial 1080 possum and rat control operations, conducted between 2003 and 2014. The primary focus of the monitoring in these operations was to compare the efficacy of the various experimental baiting treatments, but these experiments also provided the basis for the ad hoc comparison of the frequency with which dead birds were found in relation to the main experimental treatments. These included use of pre-feeding, deer repellent, and cluster and strip sowing (i.e. methods absent from, or poorly represented in, the data set analysed by Veltman and Westbrooke (2011)). We focus on characterising the species composition among dead birds found after aerial 1080 operations, and also present some preand post-poisoning counts of live bird relative abundance from two of the operations to help interpret our results. Finally, we report on the frequency of measurable 1080 residues in many of the bird carcasses recovered.

\section{Methods}

\section{Sources of bird data from 1080 operations}

Bird by-kill data were obtained from searches undertaken in conjunction with pest monitoring activity following 15 aerial 1080 operations conducted between 2003 and 2014. These 15 pest control operations were mostly conducted by either TBfree New Zealand (formerly the Animal Health Board; Livingstone et al. 2015) to control or eliminate bovine tuberculosis from local possum populations $(53 \%)$ or by the Department of Conservation (DOC) for native biodiversity protection (33\%); or jointly by both agencies (7\%). In addition, one operation (7\%) was conducted by Landcare Research for experimental possum population reduction.

\section{Pest control operational details}

All of the toxic-baiting treatments used 1080 incorporated into bait at $0.15 \% \mathrm{w} / \mathrm{w}$, with cinnamon or orange oil as a masking agent and lure (NPCA 2010). The bait in 14 of the 15 operations used was cereal pellets, either RS5 or Wanganui No. 7 (Animal Control Products, Wanganui, New Zealand); one operation (the first in 2003 with two treatments) used carrot bait cut to size and surface-coated with dye and 1080 solution at the aircraft loading site.

The 15 aerial 1080 operations monitored included 39 permutations of baiting treatments (operational details and treatment variables outlined in Table 1). Three different methods were used to aerially sow bait: broadcast, strip and cluster sowing. In brief: broadcast sowing uses buckets slung under helicopters that spread bait laterally in every direction, giving a relatively uniform spread of bait across the treated area (Nugent et al. 2010); with cluster sowing bait is periodically released along widely spaced flight paths (up to $100 \mathrm{~m}$ apart) resulting in clusters of high bait density on only $3-5 \%$ of the baited area (Nugent \& Morriss 2013). The same approach is used for strip sowing, except bait is released continuously rather than in clusters, which enables fixed-wing aircraft to be used as well as helicopters (Nugent et al. 2012).

The area-wide sowing rates of toxic bait varied almost 100 -fold among the 15 operations $\left(0.06-5.00 \mathrm{~kg} \mathrm{ha}^{-1}\right)$, being lowest for cluster sowing (11 treatments ranging $0.06-0.60$ $\mathrm{kg} \mathrm{ha}^{-1}$ ), somewhat higher for strip sowing (11 treatments ranging $0.25-1.00 \mathrm{~kg} \mathrm{ha}^{-1}$ ) and highest for broadcast sowing (16 treatments ranging $1.00-5.00 \mathrm{~kg} \mathrm{ha}^{-1}$ for 15 treatments plus one 'modified broadcast' treatment at the unusually low level of $0.5 \mathrm{~kg} \mathrm{ha}^{-1}$, which was due to the experimental deployment of $40 \mathrm{~m}$ gaps between baited areas for that one treatment).

All but one operation(Clarence Reserve 2011) incorporated prefeeding to encourage subsequent toxic bait uptake. Prefeeding used non-toxic bait of the same type used for the toxic baiting, mostly just once before toxic bait deployment, but twice in two operations (Hauhungaroa 2013 and Hokonui 2014). Deer repellent was used in 7 (18\%) different baiting treatments in 4 of the 15 operations (Table 1 ).

\section{Primary monitoring activities}

In each of the fifteen operations, some form of post-control monitoring of control outcomes was undertaken involving 12-216 days of field effort. Monitoring comprised a trapcatch index of possum abundance (Residual Trap Catch Index (RTCI); NPCA 2015) in six operations, chew card indices (CCIs; Sweetapple \& Nugent 2011) of possum and rodent abundance in nine operations, tracking tunnel indices (TTIs; King \& Edgar 1977) of rodent and stoat (Mustela erminea) abundance in five, and the survival of radio collared possums (Nugent et al. 2013) in four operations; more than one method was employed in some of the operations. In addition, systematic deer carcass searches were conducted in five operations (to assess the effectiveness of deer repellent in reducing non-target deer deaths) and 5-minute bird counts (5MBC; Dawson \& Bull 1975) were conducted in two operations (to assess the impact of 1080 poisoning on the relative abundance of birds).

Monitoring was undertaken by field teams of $2-8$ staff, with one of the authors (GM) involved in post-poison monitoring in all but two of the operations (Isolated Hill and Cascade). Field work usually started about two weeks after poisoning (range: 1-4 weeks), but on one occasion as early as three days afterward (Hokonui). Most trips were for two weeks.

\section{Incidental observation and collection of dead birds}

During the various monitoring activities above, field staff were instructed via a consistent briefing from the project leader(GM) to look for dead birds (and dead mammals) and to record the location (grid reference) of carcasses found. Bird carcasses were collected whole, assigned a tag number and, as soon as practical, frozen to stop further decomposition. Initially (2003-2008 operations) all bird carcasses found (introduced and native) were analysed for 1080 residues; but in some of the operations after 2008 only native species were analysed for 1080 residue. Carcasses considered to be too decomposed to warrant residue analysis (i.e. with no tissue present) were discarded after species identification. 
Table 1. Summary of fifteen aerial 1080 pest control operations implemented 2003-14. Data include operational specifications, field-days of monitoring post-poisoning, and dead birds found and analysed for 1080 residue. All toxic bait used contained $0.15 \% 1080$.

\begin{tabular}{|c|c|c|c|c|c|c|c|c|c|c|c|c|c|}
\hline Site & Location & $\begin{array}{l}\text { Repellent } \\
(\mathbf{Y}=1, \\
\mathbf{N}=\mathbf{0})\end{array}$ & $\begin{array}{l}\text { Bait } \\
\text { type }\end{array}$ & $\begin{array}{l}\text { Sowing } \\
\text { method }\end{array}$ & $\begin{array}{l}\text { Prefed } \\
(Y=1,2 ; \\
N=0)\end{array}$ & $\begin{array}{l}\text { Toxic bait } \\
\text { sowing } \\
\text { rate } \\
\left(\mathrm{kg} \mathrm{ha}^{-1}\right)\end{array}$ & $\begin{array}{l}\text { Size of } \\
\text { area } \\
\text { treated } \\
\text { (ha) }\end{array}$ & $\begin{array}{l}\text { Dead } \\
\text { birds } \\
\text { found } \\
(Y, N)\end{array}$ & $\begin{array}{l}\text { Dead } \\
\text { birds } \\
\text { (all) }\end{array}$ & $\begin{array}{l}\text { Dead } \\
\text { birds } \\
\text { analysed }\end{array}$ & $\begin{array}{l}\text { Dead } \\
\text { birds } \\
1080+\end{array}$ & $\begin{array}{l}\text { Field } \\
\text { days }\end{array}$ & $\begin{array}{l}\text { Dead } \\
\text { birds } \\
\text { found } \\
\text { per } \\
\text { field day }\end{array}$ \\
\hline 1 & Tataraakina & 1 & Carrot & Broadcast & 1 & 5.00 & 2000 & $\mathrm{Y}$ & 1 & 1 & 1 & 54.0 & 0.02 \\
\hline 1 & Tataraakina & 0 & Carrot & Broadcast & 1 & 5.00 & 2000 & $\mathrm{Y}$ & 1 & 0 & & 18.0 & 0.06 \\
\hline 2 & Pohokura & 1 & No7 & Broadcast & 1 & 3.00 & 1074 & $\mathrm{Y}$ & 6 & 6 & 6 & 40.0 & 0.15 \\
\hline 2 & Pohokura & 0 & No7 & Broadcast & 1 & 3.00 & 1446 & $\mathrm{Y}$ & 10 & 10 & 10 & 40.0 & 0.25 \\
\hline 3 & Blue Mountains & 1 & No7 & Broadcast & 1 & 2.00 & 6444 & $\mathrm{Y}$ & 8 & 6 & 5 & 52.0 & 0.15 \\
\hline 4 & Landsborough & 0 & No7 & Broadcast & 1 & 3.00 & 1167 & $\mathrm{~N}$ & & & & 13.5 & 0.00 \\
\hline 4 & Landsborough & 0 & No7 & Cluster & 1 & 0.25 & 1505 & $\mathrm{~N}$ & & & & 13.5 & 0.00 \\
\hline 5 & Isolated Hill & 0 & RS5 & Broadcast & 1 & 3.00 & 1213 & $\mathrm{Y}$ & 10 & 0 & & 25.0 & 0.40 \\
\hline 5 & Isolated Hill & 0 & RS5 & Cluster & 1 & 0.25 & 1385 & $\mathrm{Y}$ & 4 & 0 & & 25.0 & 0.16 \\
\hline 6 & Whanganui NP & 0 & No7 & Broadcast & 1 & 2.00 & 3021 & $\mathrm{~N}$ & & & & 16.5 & 0.00 \\
\hline 6 & Whanganui NP & 0 & No7 & Cluster & 1 & 0.60 & 1884 & $\mathrm{~N}$ & & & & 16.5 & 0.00 \\
\hline 6 & Whanganui NP & 0 & No7 & Strip & 1 & 0.45 & 1339 & $\mathrm{~N}$ & & & & 16.5 & 0.00 \\
\hline 6 & Whanganui NP & 0 & No7 & Strip & 1 & 0.25 & 1571 & $\mathrm{~N}$ & & & & 16.5 & 0.00 \\
\hline 7 & Cascade & 0 & RS5 & Broadcast & 1 & 2.00 & 26704 & $\mathrm{Y}$ & 1 & 0 & & 17.5 & 0.06 \\
\hline 7 & Cascade & 0 & RS5 & Cluster & 1 & 0.25 & 1319 & $\mathrm{Y}$ & 1 & 0 & & 17.5 & 0.06 \\
\hline 7 & Cascade & 0 & RS5 & Cluster & 1 & 0.17 & 1374 & $\mathrm{~N}$ & & & & 17.5 & 0.00 \\
\hline 8 & Maruia & 0 & RS5 & Broadcast & 1 & 2.00 & 440 & $\mathrm{~N}$ & & & & 10.0 & 0.00 \\
\hline 8 & Maruia & 0 & RS5 & Cluster & 1 & 0.25 & 770 & $\mathrm{Y}$ & 2 & 0 & & 27.0 & 0.07 \\
\hline 8 & Maruia & 0 & RS5 & Cluster & 1 & 0.20 & 440 & $\mathrm{~N}$ & & & & 10.0 & 0.00 \\
\hline 8 & Maruia & 0 & RS5 & Cluster & 1 & 0.17 & 440 & $\mathrm{~N}$ & & & & 10.0 & 0.00 \\
\hline 9 & Clarence Reserve & 0 & RS5 & Cluster & 1 & 0.30 & 2000 & $\mathrm{~N}$ & & & & 6.0 & 0.00 \\
\hline 9 & Clarence Reserve & 0 & RS5 & Cluster & 0 & 0.06 & 2000 & $\mathrm{~N}$ & & & & 6.0 & 0.00 \\
\hline 10 & Whanganui NP & 0 & RS5 & Broadcast & 1 & 1.00 & 1150 & $\mathrm{~N}$ & & & & 32.0 & 0.00 \\
\hline 10 & Whanganui NP & 0 & RS5 & Cluster & 1 & 0.50 & 2209 & $\mathrm{Y}$ & 1 & 0 & & 32.0 & 0.03 \\
\hline 10 & Whanganui NP & 0 & RS5 & Strip & 1 & 0.50 & 1269 & $\mathrm{Y}$ & 1 & 0 & & 32.0 & 0.03 \\
\hline 11 & Hauhungaroa & 1 & No7 & Broadcast & 1 & 1.50 & 13811 & $\mathrm{~N}$ & 1 & 1 & 0 & 27.0 & 0.04 \\
\hline 11 & Hauhungaroa & 0 & No7 & Broadcast & 1 & 1.50 & 5308 & $\mathrm{Y}$ & 2 & 2 & 0 & 27.0 & 0.07 \\
\hline 11 & Hauhungaroa & 0 & No7 & Strip & 1 & 1.00 & 1580 & $\mathrm{~N}$ & & & & 27.0 & 0.00 \\
\hline 11 & Hauhungaroa & 1 & No7 & Strip & 1 & 0.70 & 2982 & $\mathrm{Y}$ & 3 & 3 & 1 & 27.0 & 0.11 \\
\hline 11 & Hauhungaroa & 0 & No7 & Strip & 1 & 0.70 & 1820 & $\mathrm{Y}$ & 5 & 5 & 4 & 27.0 & 0.19 \\
\hline 11 & Hauhungaroa & 0 & No7 & Strip & 1 & 0.67 & 3052 & $\mathrm{~N}$ & & & & 27.0 & 0.00 \\
\hline 11 & Hauhungaroa & 1 & No7 & Strip & 1 & 0.47 & 5303 & $\mathrm{~N}$ & & & & 27.0 & 0.00 \\
\hline 11 & Hauhungaroa & 0 & No7 & Strip & 1 & 0.47 & 5420 & $\mathrm{~N}$ & & & & 27.0 & 0.00 \\
\hline 12 & Whanganui NP & 0 & No7 & Broadcast & 1 & 1.00 & 1774 & $\mathrm{~N}$ & & & & 24.0 & 0.00 \\
\hline 12 & Whanganui NP & 0 & No7 & Strip & 1 & 0.50 & 1764 & $\mathrm{~N}$ & & & & 24.0 & 0.00 \\
\hline 13 & Hauhungaroa & 0 & RS5 & Broadcast & $2^{1}$ & 1.50 & 10723 & $\mathrm{Y}$ & 10 & 4 & 1 & 34.0 & 0.29 \\
\hline 13 & Hauhungaroa & 0 & RS5 & $\begin{array}{l}\text { Modified } \\
\text { broadcast }\end{array}$ & $2^{1}$ & 0.50 & 4872 & $\mathrm{Y}$ & 5 & 1 & 1 & 34.0 & 0.15 \\
\hline 14 & Hokonui & 1 & RS5 & Broadcast & $2^{1}$ & 1.50 & 9166 & $\mathrm{~N}$ & 7 & 7 & 6 & 38.0 & 0.18 \\
\hline 15 & Clarence Valley & 0 & RS5 & Strip & 1 & 0.50 & 9906 & $\mathrm{Y}$ & 2 & 0 & & 16.0 & 0.13 \\
\hline
\end{tabular}

${ }^{1}$ Prefed twice

\section{Laboratory assay for 1080 residues in bird tissues}

The 1080 concentrations in bird muscle tissue were measured by high pressure liquid chromatography. Measurements were undertaken in an IANZ-accredited analytical toxicology laboratory (Landcare Research, Lincoln, New Zealand), using the tissue preparation methods and assay techniques described in detail by Pain et al. (2008). The method detection limit was $0.001 \mathrm{mg} \mathrm{kg}^{-1}$ and the method precision $(95 \% \mathrm{CI})$ was $\pm 9 \%$ of the measurement value.

\section{Relative abundance of blackbirds (Hauhungaroa 2011, 2013)}

Blackbirds comprised more than two thirds of the dead birds found. To help interpret this finding, we compared the species composition of the sample of dead birds found with the relative abundance of live birds in the Hauhungaroa 2011 and 2013 operations. Live bird relative abundance was indexed by a standardised field quantification method, namely the $5 \mathrm{MBC}$, as described originally by Dawson and Bull (1975) with modern- 
practice updates as described by Hartley (2012). Counts were conducted before and immediately after aerial 1080 poisoning in four or six blocks, and also in two other nearby blocks not poisoned at those times. These central North Island study areas comprised mostly mixed podocarp-broadleaved forest with scattered rimu (Dacrydium cupressinum) and mataī (Prumnopitys taxifolia) over broadleaved canopies dominated by tawa (Beilschmiedia tawa) or tāwheowheo (Quintinia serrata). The 1080 baiting treatments included both strip- and broadcast-sowing in 2011, and two forms of broadcast baiting in 2013, one with $12 \mathrm{~g}$ cereal baits and the other with 6-8 g baits (Table 1).

In each of the blocks, parallel transects spaced $200 \mathrm{~m}$ apart were established and five-minute counts were made at count stations spaced at $200 \mathrm{~m}$ intervals along those transects. During each $5 \mathrm{MBC}$, all birds seen or heard within $100 \mathrm{~m}$ of the stationary observer were recorded (Hartley 2012). Prepoisoning counts were conducted in late autumn/early winter and post-poisoning counts in late winter/spring. Generally, the same observers conducted both the pre- and post-poisoning counts in each block.

\section{Data handling and statistical analyses}

We first evaluated the overall number and type of dead birds found, and the presence or absence of 1080 residues within them. We next calculated the total numbers of birds found per unit effort for each operation using the number of field days as the measure of survey effort, with each field day representing an average of about 7 hours spent by a single observer walking between locations and conducting various primary monitoring tasks. In all cases most of the time was spent walking between monitoring stations.

All statistical analyses were undertaken in the R Statistical Computing Environment, version 2.13.0 (R development core team 2010). For between-treatment quantitative comparisons, analysis of the numbers of dead birds found utilised effort (i.e. the number of monitoring field days) as a co-variate. We did not include observer as a factor in these analyses because the large number of observers used over the 12 years and widely separate regions meant most observers only participated in one or two surveys, which (given the low rate at which carcasses were found) results in there being too little power to assess observer differences.

Initial investigation indicated that these data were over dispersed, consequently data were $\log _{\mathrm{e}}$-transformed and a quasi-Poisson distribution was fitted. Poisson regression was then used to evaluate the effects of different parameters applied to aerial sowing including: different sowing methods (broadcast, strip- or cluster-sowing); presence or absence of deer repellent on the poison bait; and different toxic bait sowing rates. All bird carcasses found were included in these analyses to maximise sample size, even though not all of them would have contained 1080 (hence, strictly speaking, our statistical results relate to all causes of bird death within treatment areas, i.e. 1080-related and non-1080). In doing this, we implicitly assumed that the proportion of bird carcasses found that had died of causes other than 1080 would be a random effect across all areas unrelated to 1080-related treatment variables. We estimate that non-1080 deaths accounted for less than $20 \%$ of the carcasses found, making it unlikely that that source of variation would greatly affect the results. Because almost all of the introduced birds but few of the native species tested contained 1080, the assumption means the impact on native species is likely to be overstated.

\section{Results}

\section{Bird carcass observations and collections}

Linear distance covered by field staff each field-day during post-operational monitoring varied between $3 \mathrm{~km}$ and $10 \mathrm{~km}$, with an average of $5 \mathrm{~km}$ per day traversed. Carcass searching was typically limited by ground cover to (we estimate) about $2 \mathrm{~m}$ to either side of the travel routes, suggesting a coverage area of approximately 2 ha per field day. Over the entire study of 987 field days we therefore searched about 2000 ha, but because the routes to and from pest monitoring devices (traps, tunnels, chewcards) were often the same, only approximately half of this area would have been 'new' territory covered for each device deployment and collection/recovery trip.

We found 81 dead birds ( $84 \%$ introduced and $16 \%$ native) in 987 field-days (at a mean rate of 0.08 dead birds per day; range $0.00-0.40$ per day within treatments; Tables $1 \& 2$ ). These comprised 55 blackbirds (Turdus merula), eight kererū (Hemiphaga novaeseelandiae), eight chaffinches (Fringilla coelebs), three dunnocks (Prunella modularis), two tomtits (Petroica macrocephala), two thrushes (Turdus philomelos), one tūī (Prosthemadera novaeseelandiae), one silvereye (Zosterops lateralis) and one fantail (Rhipidura fuliginosa).

Most $(85 \%)$ of the native birds and half $(52 \%)$ of the introduced birds were analysed for 1080 residues (Table 2). Only tomtits had 1080 residues among the 11 native birds assayed (Table 2). In contrast, almost all (33 of 35; 94\%) of the introduced birds assayed contained 1080, including 25 of $26(96 \%)$ of the blackbirds assayed, in which muscle tissue 1080 concentrations of up to $32 \mathrm{mg} \mathrm{kg}^{-1}$ were recorded.

\section{Statistical comparison between 1080 baiting treatments}

Treatment comparisons provided weak evidence of a positive relationship between the area-wide toxic bait sowing rate and the number of dead birds found per unit search effort $\left(\mathrm{F}_{1,37}=\right.$ $3.11, p=0.09)$. When sowing rate specifications were grouped into two classes (i.e. $<1 \mathrm{~kg} \mathrm{ha}^{-1}$ or $\geq 1 \mathrm{~kg} \mathrm{ha}^{-1}$ ) a mean of 0.1 dead birds was recorded per field day for areas sown with toxic bait at rates equal to or above $1 \mathrm{~kg} \mathrm{ha}^{-1}$ ( 57 dead birds found in 495 field days) compared to 0.04 dead birds per day (24/455) in areas sown with less than $1 \mathrm{~kg} \mathrm{ha}^{-1}$. Overall, the greatest numbers of dead birds found were following operations that had used the highest sowing rates (Fig. 1a). In line with that, significantly more birds per unit search effort were found dead in areas where bait was broadcast (mostly at $1.0-5.0 \mathrm{~kg} \mathrm{ha}^{-1}$ ) than in areas where strip or cluster sowing (at $\left.0.06-1.0 \mathrm{~kg} \mathrm{ha}^{-1}\right)$ was used $\left(\mathrm{F}_{2,36}=7.10, p<0.001\right)$. On average, approximately three times as many dead birds were found per broadcast aerial 1080 operation than for either alternative sowing method (cluster or strip sowing; Fig. 1b). There was no significant difference in the number of dead birds found per unit search effort when deer repellent was used with toxic bait compared with unmodified toxic bait $\left(\mathrm{F}_{1,37}=1.60, p=0.21\right)$.

\section{Relative abundance of blackbirds (Hauhungaroa 2011, 2013)}

From those blocks where 5MBC were conducted, 11 dead birds (six blackbirds, four kererū, and one fantail) were found after the pest control operation in 2011 and 15 (eleven blackbirds, three kererū, and one tūî) after the operation in 2013. All 26 bird carcasses were recovered from the poisoned blocks, with the rate of dead bird discovery being three times higher in 2013 than in 2011 ( 0.22 per day compared to 0.07 per day 
Table 2. Number of birds (by species) found dead during monitoring of 15 aerial 1080 poisoning operations conducted 2003-14. The number of field days of survey is shown. Also shown is the number of dead birds tested for 1080 residues and the range of muscle tissue concentrations observed.

\begin{tabular}{|c|c|c|c|c|c|}
\hline Location & Year & Field days & No. and species & No. analysed & 1080 residue analyses $\left(\mathrm{mg} \mathrm{kg}^{-1}\right)$ \\
\hline $\begin{array}{l}\text { Tataraakina } \\
\text { Pohokura }\end{array}$ & $\begin{array}{l}2003 \\
2005\end{array}$ & $\begin{array}{l}72 \\
80\end{array}$ & $\begin{array}{l}2 \text { blackbirds } \\
11 \text { blackbirds } \\
1 \text { dunnock } \\
2 \text { chaffinch } \\
2 \text { tomtit }\end{array}$ & $\begin{array}{l}1 \\
11 \\
1 \\
2 \\
2\end{array}$ & $\begin{array}{l}0.01 \\
6.90-32.00 \\
1.70 \\
1.40-5.80 \\
0.23-0.75\end{array}$ \\
\hline Blue Mountains & 2008 & 52 & $\begin{array}{l}7 \text { blackbirds } \\
1 \text { kererū }\end{array}$ & $\begin{array}{l}5 \\
1\end{array}$ & $\begin{array}{l}0.003-28.40 \\
<\mathrm{MDL}^{1}\end{array}$ \\
\hline Landsborough & 2009 & 27 & 0 & - & - \\
\hline Isolated Hill & 2009 & 50 & $\begin{array}{l}11 \text { blackbirds } \\
2 \text { chaffinch } \\
1 \text { silvereye }\end{array}$ & $\begin{array}{l}- \\
-\end{array}$ & $\begin{array}{l}- \\
- \\
-\end{array}$ \\
\hline Whanganui NP & 2009 & 66 & 0 & - & - \\
\hline Cascade & 2010 & 53 & 2 blackbirds & - & - \\
\hline Maruia & 2010 & 57 & 2 blackbirds & - & - \\
\hline Clarence Reserve & 2011 & 12 & 0 & - & - \\
\hline Whanganui NP & 2011 & 96 & 2 blackbirds & - & - \\
\hline Hauhungaroa & 2011 & 216 & $\begin{array}{l}5 \text { blackbirds } \\
1 \text { blackbird } \\
4 \text { kererū } \\
1 \text { fantail }\end{array}$ & $\begin{array}{l}5 \\
1 \\
4 \\
1\end{array}$ & $\begin{array}{l}0.27-1.73 \\
<\mathrm{MDL} \\
<\mathrm{MDL} \\
<\mathrm{MDL}\end{array}$ \\
\hline Whanganui NP & 2012 & 48 & 0 & - & - \\
\hline Hauhungaroa & 2013 & 68 & $\begin{array}{l}11 \text { blackbird } \\
3 \text { kererū } \\
1 \text { tūī }\end{array}$ & $\begin{array}{l}2 \\
2 \\
1\end{array}$ & $\begin{array}{l}0.48-1.66 \\
<\mathrm{MDL} \\
<\mathrm{MDL}\end{array}$ \\
\hline Hokonui & 2014 & 38 & $\begin{array}{l}1 \text { blackbird } \\
2 \text { chaffinch } \\
1 \text { chaffinch } \\
2 \text { dunnock } \\
1 \text { thrush }\end{array}$ & $\begin{array}{l}1 \\
2 \\
1 \\
2 \\
1\end{array}$ & $\begin{array}{l}13.60 \\
2.71-4.76 \\
<\mathrm{MDL} \\
0.28-1.54 \\
2.01\end{array}$ \\
\hline Clarence Valley & 2014 & 16 & $\begin{array}{l}1 \text { chaffinch } \\
1 \text { thrush }\end{array}$ & - & $\begin{array}{l}- \\
-\end{array}$ \\
\hline
\end{tabular}

${ }^{1}<\mathrm{MDL}=$ below the method detection limit of $0.001 \mathrm{mg} \mathrm{kg}^{-1}$

a)

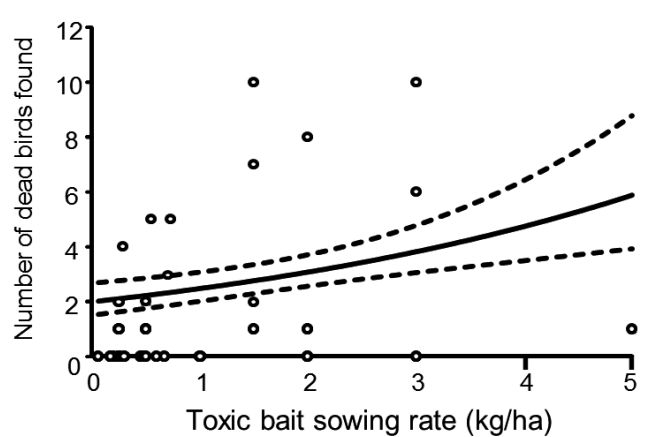

b)

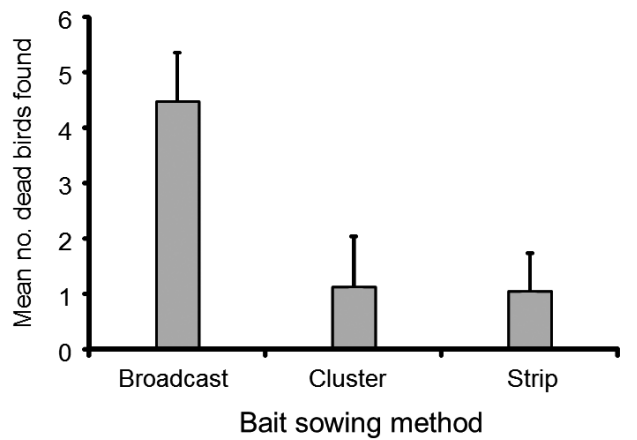

Figure 1. Numbers of dead birds found post-aerial 1080 baiting operations according to different baiting treatments. Numbers of birds found dead (unweighted by effort):

(a) in relation to overall (area-wide) toxic bait sowing rate (circular symbols represent 39 different treatment permutations used over 15 different operations; solid line represents a regression-fitted relationship, dashed lines represent $1 \mathrm{SE}$ above and below the regression)

(b) per operational permutation for three bait sowing techniques (i.e. used in different study areas) for 17 cases of broadcast sowing and 11 each of cluster or strip sowing (mean values depicted as histogram columns with 1SE above the means as bars). 


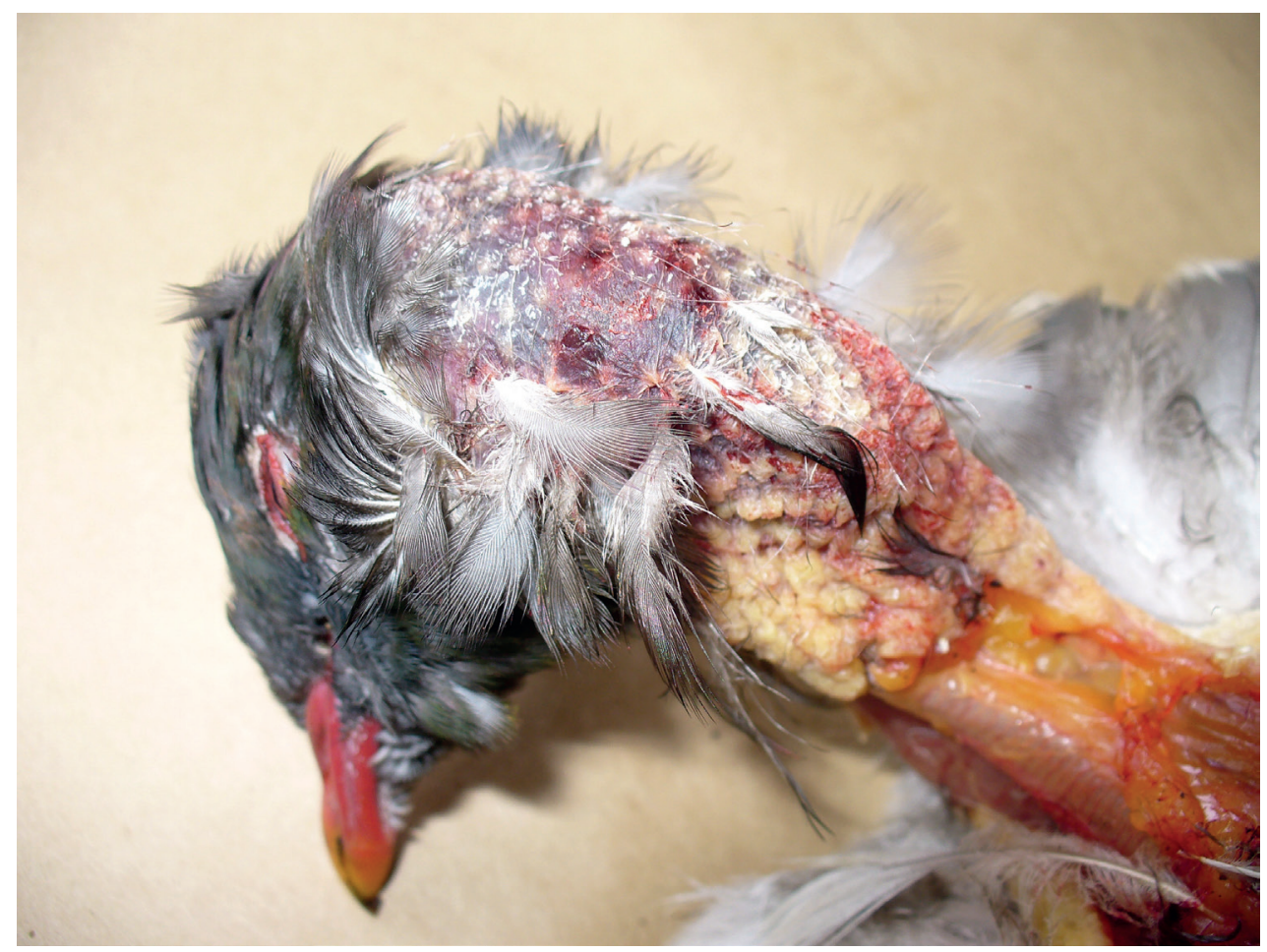

Figure 2. Photograph of one of the two dead kerurū found post-aerial 1080 poisoning, Hauhungaroa 2011. Note the predator bite marks (most likely stoat) on the back of the kerurū's head.

respectively). Two of the kererū found in 2011 bore obvious signs of predation (Fig. 2) and the fantail was found freshly dead after a heavy snowfall. No 1080 residue was found in any of the eight native birds tested, but 1080 was present in seven of the eight blackbirds tested, at muscle tissue concentrations of $0.27-1.73 \mathrm{mg} \mathrm{kg}^{-1}$ (Table 2). From the two operations, we also found 102 dead small mammals in 2011 (60 possums, 38 rats, three hedgehogs and one mouse) and 51 in 2013 (27 possums, 20 rats, three hedgehogs and one cat), all in the poisoned blocks.

In 2011, 21647 counts of live birds were recorded from 33 species, with native species comprising $89 \%$ of the total live birds counted (Table 3 ). Overall counts declined by $25 \%$ in the poisoned blocks compared to $9 \%$ in the unpoisoned blocks, this difference being largely due to an observed decline in tūî counts of $48 \%$ in the treatment areas versus an observed $13 \%$ increase in the non-treatment areas. Excluding tūī $(21 \%$ of the total bird counts), the counts for all of the other species combined were similar irrespective of treatment, declining by $18 \%$ and $15 \%$ in the poisoned blocks and unpoisoned blocks respectively.

Counts in 2013 were similar, with 16,531 counts of live birds (93\% native) from 37 species in the six blocks (Table 3 ). Again, counts were overall lower (by almost a quarter) in spring than in autumn largely reflecting the pattern for native species. The overall decline varied widely between blocks, but was largest (39\%) in one of the unpoisoned blocks. Although counts declined substantially $(>10 \%)$ in some blocks for eight of the common species in Table 3, except for blackbirds the largest or second largest decline was in an unpoisoned block. Counts of the other seven commonly-counted species were mostly unchanged or increased after poisoning. In 2011, the mean blackbird count declined by $14 \%$ (Table 3 ) reflecting an overall decline of $19 \%$ in the six poisoned blocks compared to a $2 \%$ decline in the unpoisoned blocks. In 2013, blackbird counts increased by $43 \%$ in one of the two unpoisoned areas and declined by $20 \%$ in the other, whereas in four poisoned blocks all of the counts declined by $44-67 \%$ (overall average decline of $56 \%$ ). Blackbirds were the only common species for which all of the highest declines were in the poisoned blocks. Overall, blackbirds comprised $3.2 \%$ and $1.9 \%$ of the live bird counts in 2011 and 2013 respectively; the same species represented $54 \%$ and $73 \%$ respectively of the dead birds found in the Hauhungaroa surveys.

\section{Discussion}

The present analysis uses field data that are often collected, but rarely analysed in detail, from extensive mammalian pest control operations conducted in New Zealand. Despite its somewhat ad hoc nature, data collected and information presented here provide a strong indication that the impact of modern and experimental aerial 1080 baiting practices on common native birds is low. While several of the 1080 treatment applications were of an experimental nature, most studies incorporated the 'gold standard' operational practice of aerial broadcast sowing of 1080 -coated cereal baits at $\sim 1-3 \mathrm{~kg} \mathrm{ha}^{-1}$ (NPCA 2010). For the 15 operations from which we gathered data, we detected 1080 residues in 35 of the 46 bird carcasses assayed, and while this implies that at least $76 \%$ of dead birds found were likely to have ingested some 1080, only two of those (i.e. $\sim 4 \%$ of the total number assayed) were native species. This assumption is consistent with the earlier findings summarised by Spurr (2000). Moreover, our finding that most of the native dead birds found did not contain 1080 residue highlights the need by observers to avoid automatically attributing native bird deaths following aerial pest control operations to 1080 poisoning. To the contrary, the evidence here of very few native bird deaths directly attributable to 1080 underscores the suitability of this compound for mammalian pest control in New Zealand's forests (Wright 2011). Evidence presented 
Table 3. Total counts (and percentages of the total) by species, recorded during 5MBCs before (May) and after (JuneSeptember) toxic bait deployment in the Hauhungaroa 2011 and 2013 aerial 1080 baiting operations. The totals are summed across pre- and post-operational counts and across all six blocks (of which four were poisoned and two were not). Means are the number of birds detected per count station. Species comprising $<1 \%$ of the total are not shown.

\begin{tabular}{|c|c|c|c|c|c|c|c|c|}
\hline & \multicolumn{4}{|c|}{2011 aerial 1080 operation } & \multicolumn{4}{|c|}{2013 aerial 1080 operation } \\
\hline & $\begin{array}{l}2011 \\
\text { Total } \\
\text { counts }\end{array}$ & $\begin{array}{l}\% \\
\text { total }\end{array}$ & $\begin{array}{l}2011 \\
\text { Mean } \\
\text { pre } \\
\text { operation }\end{array}$ & $\begin{array}{l}2011 \\
\text { Mean } \\
\text { post } \\
\text { operation }\end{array}$ & $\begin{array}{l}2013 \\
\text { Total } \\
\text { counts }\end{array}$ & $\begin{array}{l}\% \\
\text { total }\end{array}$ & $\begin{array}{l}2013 \\
\text { Mean } \\
\text { pre } \\
\text { operation }\end{array}$ & $\begin{array}{l}2013 \\
\text { Mean } \\
\text { post } \\
\text { operation }\end{array}$ \\
\hline$N$ stations & 2078 & & 1039 & 1039 & 2052 & & 1013 & 1039 \\
\hline Silvereye Zosterops lateralis & 4921 & $22.7 \%$ & 2.04 & 1.64 & 3557 & $21.5 \%$ & 2.85 & 0.62 \\
\hline Whitehead Mohoua albicilla & 1767 & $8.2 \%$ & 0.61 & 0.72 & 2446 & $14.8 \%$ & 0.99 & 1.43 \\
\hline Tomtit Petroica macrocephala & 1862 & $8.6 \%$ & 0.77 & 0.59 & 1670 & $10.1 \%$ & 0.79 & 0.83 \\
\hline Tūī Prosthemadera novaeseelandiae & 4688 & $21.7 \%$ & 2.16 & 1.42 & 1402 & $8.5 \%$ & 0.89 & 0.47 \\
\hline Bellbird Anthornis melanura & 1155 & $5.3 \%$ & 0.56 & 0.29 & 1397 & $8.5 \%$ & 0.82 & 0.54 \\
\hline Grey warbler Gerygone igata & 1206 & $5.6 \%$ & 0.43 & 0.46 & 1293 & $7.8 \%$ & 0.32 & 0.92 \\
\hline North Island robin Petroica longipes & 1027 & $4.7 \%$ & 0.44 & 0.33 & 1276 & $7.7 \%$ & 0.55 & 0.71 \\
\hline Rifleman Acanthisitta chloris & 275 & $1.3 \%$ & 0.11 & 0.10 & 620 & $3.8 \%$ & 0.35 & 0.25 \\
\hline Kererū Hemiphaga novaeseelandiae & 1666 & $7.7 \%$ & 0.70 & 0.53 & 504 & $3.0 \%$ & 0.40 & 0.10 \\
\hline Fantail Rhipidura fuliginosa & 437 & $2.0 \%$ & 0.20 & 0.13 & 448 & $2.7 \%$ & 0.31 & 0.13 \\
\hline Chaffinch Fringilla coelebs & 785 & $3.6 \%$ & 0.29 & 0.30 & 315 & $1.9 \%$ & 0.11 & 0.20 \\
\hline Blackbird Turdus merula & 702 & $3.2 \%$ & 0.29 & 0.25 & 314 & $1.9 \%$ & 0.20 & 0.11 \\
\hline Kākāriki Cyanoramphus auriceps & 119 & $0.5 \%$ & 0.03 & 0.05 & 275 & $1.7 \%$ & 0.17 & 0.10 \\
\hline Long tailed cuckoo Eudynamys taitensis & 0 & $0.0 \%$ & 0.00 & 0.00 & 175 & $1.1 \%$ & 0.00 & 0.17 \\
\hline Song thrush Turdus philomelos & 659 & $3.0 \%$ & 0.29 & 0.19 & 171 & $1.0 \%$ & 0.01 & 0.16 \\
\hline Redpoll Carduelis flammea & 33 & $0.2 \%$ & 0.02 & 0.01 & 170 & $1.0 \%$ & 0.13 & 0.04 \\
\hline
\end{tabular}

elsewhere indicates that, overall, 1080 use can provide net benefits for native bird communities, by reducing predation pressure and (for example) increasing consequent nesting and fledging success, as reported from studies on breeding North Island robin (Petroica australis longipes; Powlesland et al. 1999) and North Island kōkako (Callaeas wilsoni; Innes et al. 1999).

Native forests typically contain higher densities of common native birds than of European garden birds, in some cases up to 60 times higher (MacLeod et al. 2012). While we have not analysed in any depth the changes in Hauhungaroa live bird counts for native species before and after 1080 poisoning, some preliminary points stand out. First, in both years of the Hauhungaroa studies (2011 and 2013) overall counts were lower in spring than in autumn, in both poisoned and unpoisoned areas, strongly suggesting major seasonal variation in bird counts irrespective of mammalian pest control operations. Secondly, counts of native birds were highly idiosyncratic with changes sometimes varying greatly between blocks subject to the same experimental treatment, suggesting that there are area (block) effects on season as well. There were very few instances in which there appeared to be a reduction in native bird counts that was consistently greater in poisoned areas than in unpoisoned areas. One notable exception was the large decline in tūî counts in all Hauhungaroa blocks after poisoning in 2011, concurrent with a modest increase in tūī counts from unpoisoned areas. However, because we found no dead tūī that year (even though they are the same black colouration and size as blackbirds), we are confident that this difference must reflect some large scale movement of tūī out of some blocks (and possibly into others). In support of this, Berquist $(1985,1989)$ noted that tūî regularly forage for nectar sources in family groups over distances of 5-35 km, distances that would easily carry them far outside our experimental blocks (which were a few thousand hectares in size). Natural fluctuations in native bird numbers in forests, sufficient to confound interpretation of non-target outcomes from pest control operations, have been noted by others: for example, Oates (2008) and Greene et al. (2013) recorded marked declines in localised tomtit relative abundance following 1080 operations (in Rotoaira and Waitutu forests respectively), however both sets of authors noted that these declines were (apparently) unrelated to treatment variables, since they were observed in non-treatment (control) blocks in addition to poisoned blocks.

By contrast to our conclusions on native bird species, our results suggest that aerial poison operations probably have a detrimental effect on blackbirds and possibly also some other common introduced bird species such as chaffinches, thrushes and dunnocks. Levels of 1080 residue in blackbird muscle exceeded $10 \mathrm{mg} \mathrm{kg}^{-1}$ in 3 of 6 reports where blackbird tissues had been analysed. These levels exceed those cited by Fairweather et al. (2014) in a review of several aerial 1080 operations (where 1080 residue levels up to $5.9 \mathrm{mg} \mathrm{kg}^{-1}$ had been reported). The comparatively large number of dead blackbirds found relative to other species in the present studies may reflect, in part, their presence in all operational areas; by contrast native species such as tūī (for example) were believed to have been present in only eight of the fifteen operational areas (53\%). Across both Hauhungaroa surveys (2011 and 2013), blackbirds comprised $3 \%$ of live bird counts recorded but two-thirds of the dead birds found, and probably close to $90 \%$ of those likely to have been killed by 1080 . The behaviour of blackbirds is likely to contribute to their risk of poisoning; they are omnivorous and frequently forage on the forest floor 
where the majority of bait would be present, and therefore have many opportunities to encounter and eat bait or contaminated invertebrates. It is, of course, theoretically possible that live blackbirds may have been less conspicuous than other species being seen or heard, although data from elsewhere suggest this unlikely; Meadows et al. (2012) reported that introduced species were generally more conspicuous than native species and estimated that the probability of detecting a blackbird within $10 \mathrm{~m}$ of an observer was 0.8 , compared to similar or lower probabilities of 0.3-0.9 for six native species (bellbird, fantail, grey warbler, rifleman, silvereye and tomtit). Likewise, Moffat and Minot (1994) reported that blackbird density in the Tararua Ranges was still an order of magnitude lower than that of most of the common native bird species, even when corrected for differences in detectability. Moffat and Minot (1994) calculated that a mean 5MBC of 0.21 blackbirds per station equated to 0.10 blackbirds per ha averaged across the five transects reported. Using that as a calibration for our results, the pre-poison counts of 0.27 and 0.15 blackbirds per station that we recorded from the Hauhungaroa surveys of 2011 and 2013 (respectively) would suggest comparatively low blackbird densities in this native forest habitat, possibly in the same range as previously-reported New Zealand blackbird densities of about 0.10 per ha (reported for woody shrubland by Wilson et al. (2014) and for native forest by MacLeod et al. (2012)). Based on the declines in counts in poisoned areas relative to those in the unpoisoned areas, and averaged across the two operations, our results suggest that 1080 operations could have reduced blackbird numbers substantially, possibly by about a third. If so, and if blackbirds did indeed comprise only $3 \%$ of the total bird community, this suggests the blackbird reduction equated to $1 \%$ of all birds. If all of that reduction was attributed to 1080 poisoning, we infer from the lower number of native birds found dead in the Hauhungaroa operations compared to blackbirds (9 vs 17) and the much lower percentage of native species containing 1080 residues $(0 \%$ of 8 assayed vs $87 \%$ of 8 assayed), that the 1080 -caused reduction in native bird numbers was likely to have been well below $1 \%$, given that native species comprised $89 \%$ of the counts. Thus, we conclude, subject to the validity of our various assumptions about the carcass detectability and conspicuousness of all native birds combined relative to blackbirds, that the effect of 1080 operations on the Hauhungaroa bird community as a whole was very low, and even lower on native birds.

Our results suggest that overall bird deaths (as standardised per unit of search effort) were positively correlated with the area-wide toxic bait sowing rates employed, with that pattern undoubtedly being driven mainly by the effect on blackbirds. It is not clear whether that is an effect of sowing rate per se, or of the sowing technique, because the 'modern' methods of clusterand strip-sowing were used only at low rates and 'traditional' broadcast sowing only at comparatively high rates (with one exception for an experimental 'modified broadcast' treatment). Nevertheless, results suggest that leaving much of the overall operational area unbaited (as with strip-sowing) can reduce the subsequent incidental by-kill risk, at least for a species that seems highly vulnerable i.e. blackbirds. Possibly, this somehow reflects a reduced likelihood of blackbirds encountering 1080 bait or invertebrates that have fed on 1080 bait (Heather \& Robertson 2005). Adult blackbirds are highly territorial year round, with small non-exclusive territories of 0.16-0.24 ha recorded in Britain (Snow 1956). Peri-urban blackbirds in New Zealand appear to also be similarly sedentary (Bull 1958) with breeding territories likely to often be less than $80 \mathrm{~m}$ across
(Gurr 1954). Territories of that size could therefore fit entirely within the 60-80 m unbaited areas between the narrow baited areas produced by strip- and cluster-sowing, which would plausibly explain the lower numbers of dead birds found in such operations. The Hauhungaroa live bird count data are consistent with this, with a lower percentage reduction in the 2013 operations after strip-sowing than after broadcast.

Overall, 27 birds (most of which, 52\%, were blackbirds) were found dead in areas where deer repellent had been used in conjunction with toxic bait, with a higher tally per unit of search effort compared to areas where deer repellent was not used, although this difference was not statistically significant. Because repellent darkens cereal bait, it may reduce the effectiveness of the green dye used to reduce the attractiveness of the 1080 baits to birds (Caithness \& Williams 1971). All but one of the 1080 operations analysed in the present study utilised prefeeding, so we cannot directly address the concern raised by Veltman and Westbrooke (2011) that the practice of prefeeding may increase the risk to birds. However, our overall results suggest that relatively few native birds (at least compared to blackbirds) were killed during these operations, which in turn suggests the risk is low.

Despite our attempts to standardise parameters across fifteen 1080 operations spanning 12 years, we acknowledge that some measurement and assessment criteria contained considerable subjectivity, and we therefore highlight some caveats around our conclusions. First, there will undoubtedly have been variation between observers, and between areas, in our ability to find dead birds. With respect to field workers' visual identification of bird carcasses, we estimated an average visibility range of $2 \mathrm{~m}$ either side of the worker; in reality, this parameter was highly variable, ranging from $\sim 4 \mathrm{~m}$ in open areas to $<0.5 \mathrm{~m}$ in areas with thick understory vegetation. Further, the estimated relative abundance of different species among those found dead could have been determined, at least in part, by the comparative conspicuousness of their carcasses; although we find no reason why dead blackbirds would have been proportionately much easier to find than other dead birds of similar or larger size. Yet further, it is possible that scavengers may have consumed bird carcasses thereby leaving few to have been observed by field workers and biasing the interpretation of results; however, we again feel this is unlikely because those scavengers present were far more likely to consume (and possibly die from) the poisoned carcasses of small mammals such as rats and possums. Overall, in spite of these hypotheses, we feel confident in concluding that few native birds died following 1080 operations and very few died directly due to 1080 intoxication: most of the native birds tested for 1080 residue contained none. Instead, in some instances, other probable causes of death were readily apparent. For example, the single fantail found dead was found immediately after heavy snow, suggesting this was an example of the high winter mortality rates known to befall fantail populations (Powlesland 1982). Two of the eight kererū found dead after 1080 baiting (and also a further kererū found before one of the operations) had puncture wounds on their heads and/or necks that were consistent with the killing method used by stoats (Cuthbert 2003).

In summary, we found no evidence that modern 1080 operations pose a substantial risk to native birds as a group, at least not in terms of immediate post-operational mortality due to toxicity and not compared to the effect on blackbirds that we observed. That of course does not rule out the possibility of significant impacts on particular individual species that 
were far less common than blackbirds in our study areas, but it does contribute to the now large body of evidence suggesting that modern aerial 1080 operations are unlikely to have major detrimental impacts on the native bird community as a whole (Veltman \& Westbrooke 2011; O’Donnell \& Hoare 2012; Greene et al. 2013; Schadewinkel 2014). To address the issue objectively in the future, it would be necessary to design a bespoke bird- and mammal-carcass collection study as an integral part of a 1080 pest-control operation, something that is technically practical, but operationally expensive and time-consuming. In the meantime, our present results suggest that further reduction in 1080 bait sowing rates (beyond the historical reductions documented by Morgan (2004) and Veltman and Westbrooke (2011)) and/or a shift to new bait delivery techniques, could reduce the overall risk to birds to below the already apparently very low levels.

\section{Acknowledgments}

We thank the many contractors who spent extended periods in the field carrying out monitoring, in particular the assistance of Chris Brausch, Nat Curnow, Andy Kinley and Pete Richie; as well as various Landcare Research current and former field staff (including, in addition to the authors, Kev Drew, Dave Latham, Nick Poutu, John Williamson and Ivor Yockney). We also thank various Landcare Research non-field staff for their assistance including: the Toxicology laboratory staff for analyses; Penny Fisher for advice on toxicological measurement parameters; Guy Forrester for statistical analyses; Frank Cross for editorial assistance in the preparation of this manuscript; and Phil Cowan and Bruce Warburton for constructive comments on an earlier draft of this manuscript. Thanks also to the journal's anonymous referees for their valuable feedback.

\section{References}

Bergquist CAL 1985. Movements of groups of tui (Prosthemaderanovaeseelandiae) in winter and settlement of juvenile tui in summer. New Zealand Journal of Zoology 12: 569-571.

Bergquist CAL 1989. Tūī sociodynamics: foraging behaviour, social organisation, and use of song by tūi in an urban area. Unpublished $\mathrm{PhD}$ thesis, University of Auckland, New Zealand. 179 p.

Bull PC 1958. Birds of the Hutt Valley. Proceedings of the New Zealand Ecological Society 11: 52-58.

Caithness TA, Williams GR 1971. Protecting birds from poisoned baits. New Zealand Journal of Agriculture 122: 38-43.

Coleman JD, Fraser KW, Nugent G 2007. Costs and benefits of pre-feeding for possum control. New Zealand Journal of Zoology 34: 185-193.

Cuthbert R 2003. Sign left by introduced and native predators feeding on Hutton's shearwaters (Puffinus huttoni). New Zealand Journal of Zoology 30: 163-170.

Dawson DG, Bull PC 1975. Counting birds in New Zealand forests. Notornis 22: 101-109.

Eason C, Miller A, Ogilvie S, Fairweather A 2011. An updated review of the toxicology and ecotoxicology of sodium fluoroacetate (1080) in relation to its use as a pest control tool in New Zealand. New Zealand Journal of Ecology 35: $1-20$.
Fairweather AAC, Broome KG, Fisher P 2014. Sodium Fluoroacetate pesticide information review. Version 2014/3. Unpublished report docdm-25427. Hamilton, New Zealand, Department of Conservation. 112 p.

Green W, Rohan M 2012. Opposition to aerial 1080 poisoning for control of invasive mammals in New Zealand: risk perceptions and agency responses. Journal of the Royal Society of New Zealand 42: 185-213.

Greene TC, Dilks PJ, Westbrooke IM, Pryde MA 2013. Monitoring selected forest bird species through aerial application of 1080 baits, Waitutu, New Zealand. New Zealand Journal of Ecology 37: 41-50.

Gurr L 1954. A study of the blackbird (Turdus merula) in New Zealand. Ibis 96: 225-261.

Hartley L 2012. Five-minute bird counts in New Zealand. New Zealand Journal of Ecology 36: 268-278.

Heather BD, Robertson HA 2005. The field guide to the birds of New Zealand. Auckland, New Zealand, Viking. 440 p.

Innes J, Hay R, Flux I, Bradfield P, Speed H, Jansen P 1999. Successful recovery of North Island kokako Callaeas cinerea wilsoni populations, by adaptive management. Biological Conservation 87: 201-214.

King CM, Edgar RL 1977. Techniques for trapping and tracking stoats (Mustela erminea); a review, and a new system. New Zealand Journal of Zoology 4: 193-212.

Livingstone P, Nugent G, de Lisle G, Hancox N 2015. Toward eradication: the effect of Mycobacterium bovis infection in wildlife on the evolution and future direction of bovine tuberculosis management in New Zealand. New Zealand Veterinary Journal 63(S1): 4-18.

MacLeod CJ,Affeld K, Allen RB, Bellingham PJ, Forsyth DM, Gormley AM, Holdaway RJ, Richardson SJ, Wiser SK 2012. Department of Conservation biodiversity indicators: 2012 assessment. Landcare Research Contract Report LC1102. Lincoln, New Zealand, Landcare Research Manaaki Whenua. 63 p.

Meadows S, Moller H, Weller F 2012. Reduction of bias when estimating bird abundance within small habitat fragments. New Zealand Journal of Ecology 36: 1-8.

Moffat M, Minot EO 1994. Distribution and abundance of forest birds in the Ruamahanga ecological area, North Island, New Zealand. New Zealand Journal of Zoology 21: $135-150$.

Morgan DR 2004. Maximising the effectiveness of aerial 1080 control of possums (Trichosurus vulpecula). PhD thesis, Lincoln University, New Zealand. 187 p.

Morriss GA2007. Epro deer repellent for baits used in possum control: review of development and use 2001-2006. Landcare Research Contract Report LC0607/147. 20 p.

National Pest Control Agencies (NPCA) 2010. National Pest Control Agencies online best practice recommendations: Aerial 1080 Pest Control Industry Guidelines. www.npca. org.nz/index.php/consultation (accessed 5 April 2015)

National Pest Control Agencies (NPCA) 2015. Possum population monitoring using the trap-catch, waxtag and chewcard methods. Standard A1, National Pest Control Agencies. 50 p.

Nugent G, Morriss GA 2013. Delivery of toxic bait in clusters: a modified technique for aerial poisoning of small mammal pests. New Zealand Journal of Ecology 37: 246-255.

Nugent G, Morgan D, Clayton R, Warburton B 2010. Improving the efficacy of aerial poisoning of brushtail possums (Trichosurus vulpecula) through reduced fragmentation of bait. International Journal of Pest Management 57: 51-59. 
Nugent G, Warburton B, Thomson C, Sweetapple P, Ruscoe WA 2011. Effect of prefeeding, sowing rate and sowing pattern on efficacy of aerial 1080 poisoning of small-mammal pests in New Zealand. Wildlife Research 38: 249-259.

Nugent G, Warburton B, Thomson C, Cross ML, Coleman MC 2012. Bait aggregation to reduce cost and toxin use in aerial 1080 baiting of small mammal pests in New Zealand. Pest Management Science 68: 1374-1379.

Nugent G, Yockney I, Whitford J, Cross ML 2013. Mortality rate and gross pathology due to tuberculosis in wild brushtail possums (Trichosurus vulpecula) following low dose subcutaneous injection of Mycobacterium bovis. Preventive Veterinary Medicine 109: 168-175.

Oates KE 2008. Non-target impact assessment of possum control methods in sectors of Rotoaira Forest, through line counts of territorial male robins and tomtits. Ohakune, New Zealand, Environment Waikato Independent Study report No. 10301.20 p.

O'Donnell CFJ, Hoare JM 2012. Quantifying the benefits of long-term integrated pest control for forest bird populations in a New Zealand temperate rainforest. New Zealand Journal of Ecology 36: 131-140.

Pain DJ, White R, Stevenson J, Bell M, Williams KK, Fisher P, Wright G 2008. Toxicity and persistence of sodium fluoroacetate (1080) in the land crab (Gecarcinus lagostoma) on Ascension Island. Wildlife Research 35: 86-92.

Powlesland MH 1982. A breeding study of the South Island fantail (Rhipidura fuliginosa fuliginosa). Notornis 29: 181-195.

Powlesland RG, Knegtmans JW, Marshall ISJ 1999. Costs and benefits of aerial 1080 possum control operations using carrot baits to North Island Robins (Petroica australis longipes), Pureora Forest Park. New Zealand Journal of Ecology 23: 149-159.

R Development Core Team 2010. R: a language environment for statistical computing. Version 2.13.0. R Foundation for Statistical Computing, Vienna, Austria.

Editorial board member: George Perry

Received 7 July 2015; accepted 25 February 2016
Schadewinkel RB, Senior AM, Wilson DJ, Jamieson IG 2014. Effects on South Island robins (Petroica australis) from pest control using aerially applied 1080 poison. New Zealand Journal of Ecology 38: 315-321.

Snow DW 1956. Territory in the blackbird (Turdus merula). Ibis 98: 438-447.

Speedy C 2005. Field trials and operational results of a deer repellent for 1080 possum baits. New Zealand Journal of Forestry 50: 27-30.

Spurr EB 1979. A theoretical assessment of the ability of bird species to recover from an imposed reduction in numbers, with particular reference to 1080 poisoning. New Zealand Journal of Ecology 2: 46-63.

Spurr EB 2000. Impacts of possum control on non-target species. In: Montague TL ed The brushtail possum. Biology, impact and management of an introduced marsupial. Lincoln, Manaaki Whenua Press. Pp. 175-186.

Sweetapple P, Nugent G 2011. Chew-track-cards: a multiplespecies small mammal detection device. New Zealand Journal of Ecology 32: 152-162.

Veltman CJ, Westbrooke IM 2011. Forest bird mortality and baiting practices in New Zealand aerial 1080 operations from 1986 to 2009. New Zealand Journal of Ecology 35: 21-29.

Warburton B, Livingstone PG 2015. Managing and eradicating tuberculosis from New Zealand wildlife. New Zealand Veterinary Journal 63(S1): 77-88.

Wilson DJ, Norbury G, Walker S 2014. How does woody succession affect population densities of passerine birds in New Zealand drylands. New Zealand Journal of Ecology 38: 257-267.

Wright J (New Zealand Parliamentary Commissioner for the Environment) 2011. Evaluating the use of 1080: predators, poisons and silent forests. Wellington, New Zealand, Office of the Parliamentary Commissioner for the Environment. 85 p. 